\title{
Caderno Seminal Digital \\ INTERTEXTUALIDADES, SÍMBOLOS E MITOS ENTRE O ROMANCE MYGALE E O FILME A PELE QUE HABITO
}

\author{
Maria Cláudia Rodrigues Alves* \\ Maria Celeste Tommasello Ramos
}

Resumo: O premiado e polêmico filme de Pedro Almodóvar A pele que habito (2011) é uma adaptação do romance Mygale (1984), do escritor francês Thierry Jonquet (1954-2009), traduzido para o português, em 2005, como Tarântula. Trata-se de uma história de terror, cheia de suspense, na qual um renomado cirurgião, Roberto Ledgard, interpretado por Antonio Bandeiras, muda, sem nenhum escrúpulo, o sexo do jovem Vicente. O que se mostra ao espectador desde as primeiras imagens do filme é, portanto, Vicente/Vera em seu novo e perfeito corpo feminino. Flashbacks esclarecem ao longo do filme os acontecimentos que culminaram na cena inicial que nos é apresentada, surpreendendo-nos e, evidentemente, chocando-

\footnotetext{
Maria Cláudia Rodrigues Alves é Doutora em Teoria Literária e Literatura Comparada (USP-2006). Atua como Professor Assistente Doutor em Língua e Literatura Francesa (Área de Francês) na Universidade Júlio de Mesquita Filho (UNESP), Instituto de Biociências, Letras e Ciências Exatas (IBILCE), Câmpus de São José do Rio Preto.

Maria Celeste Tommasello Ramos é Livre-Docente em Literatura Italiana (UNESP, 2009). Atua como Professor Adjunto em Língua Italiana, Literatura Italiana e Mitologia (Graduação) e em Teoria da Narrativa, Literatura \& Mitologia e Literatura Italiana do Século XX no Programa de Pós-Graduação em Letras da Universidade Júlio de Mesquita Filho (UNESP), Instituto de Biociências, Letras e Ciências Exatas (IBILCE), Câmpus de São José do Rio Preto.
}

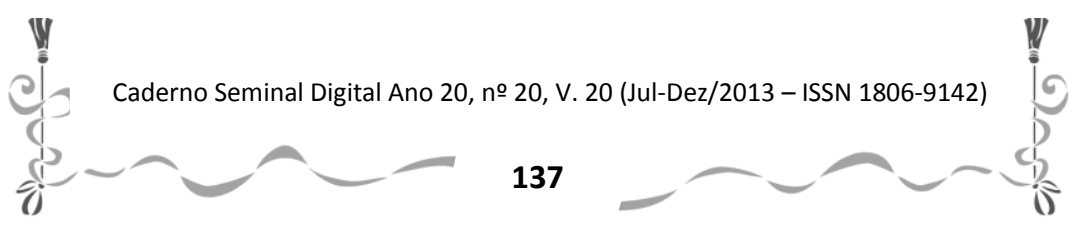




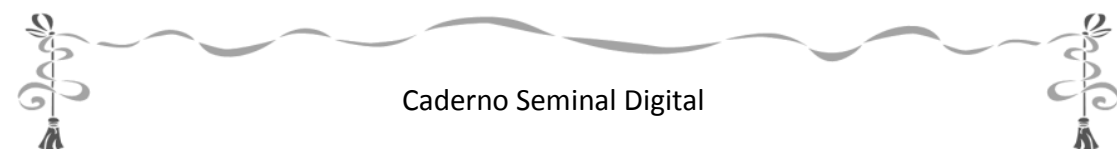

nos. Referências a mitos e símbolos podem ser notadas no filme. Elas trazem consigo, ao serem reconhecidas pelo espectador, temas ligados à criação ou à metamorfose, entre outros, como o mito de Pigmalião e Galatéia, que se liga à criação artística. Metamorfose artística operada igualmente pelo cineasta em sua versão moderna do médico e do monstro, por exemplo, mas, sobretudo, na releitura do romance de Jonquet. O presente estudo busca evidenciar alguns dos principais mitos e símbolos inseridos no filme de Almodóvar e quais interpretações tais inserções podem suscitar.

Palavras-chave: Mygale; A pele que habito; Jonquet; Almodóvar; mitos; símbolos; intertextualidades

Abstract: The award-winning and controversial movie by Pedro Almodóvar "The skin I live" (2011) is an adaptation of Mygale's novel (1984), the French writer Thierry Jonquet (1954-2009), translated into Portuguese in 2005 as Tarântula. It is a horror story, full of suspense, in which a renowned surgeon, Robert Ledgard, played by Antonio Banderas, switches, without any scruples, the sex of the young Vincent. What it shown to the viewer since the first images of the movie is, therefore, Vicente/Vera in her new and perfect female body. Flashbacks clarify during the movie the events that culminated in the opening scene that is presented to us, surprising us and, of course, shocking us. References to myths and symbols can be noticed in the movie. They bring with them, to be recognized by the viewer, issues related to the creation or metamorphosis, among others, as the Pygmalion and Galatea myth, which binds to artistic creation. Artistic metamorphosis operated equally by the filmmaker in his modern version of the doctor and the monster, for example, but, especially, in the rereading of the

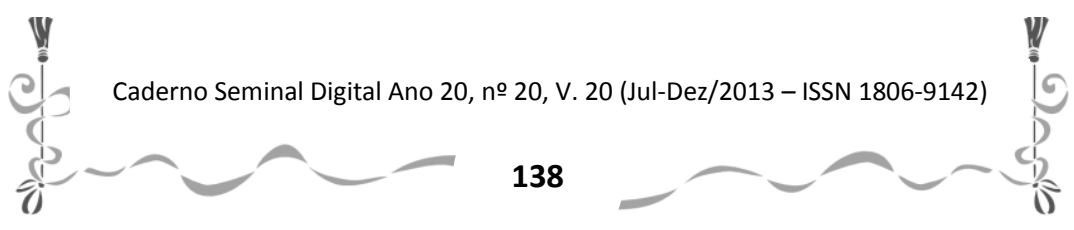


Caderno Seminal Digital

at

Jonquet's novel. This study seeks to highlight some of the major myths and symbols inserted in Almódovar's movie and what interpretations such insertions may ensue.

Keywords: Mygale; The skin I live; Jonquet; Almodóvar; myths; symbols; intertextualities.

\section{EM A PELE QUE HABITO, DE PEDRO ALMODÓVAR, OS GENES DE MYGALE, DE THIERRY JONQUET}

Ao final do filme de Pedro Almodóvar, $A$ pele que habito, após o murmúrio de Vera à sua mãe "Soy Vicente", numa cena tocante, que seguramente passará a integrar as cenas antológicas da obra almodovariana...: fade total. Do fundo negro, surge, então, ao som das primeiras notas do piano de Xavier Casado, girando, a criação de Taavi Torim: suspensa, uma cadeia de ADN estilizada, vítrea, inicialmente prateada, que adquire cores distintas em seu movimento. Vemos então revezarem-se os nomes dos atores Antonio Banderas, Elena Anaya, Marisa Paredes, Jan Cornet, Roberto Álamo, Eduard Fernández, José Luis Gómez, Blanca Suárez, Susi Sánchez, Bárbara Lennie, Fernando Cayo..., em seguida, temos a indicação da direção e da criação do roteiro, e finalmente a designação de sua origem: "Basado en la novela Mygale de Thierry Jonquet Éditions Gallimard" (1989). É imperativo esclarecermos que, à primeira leitura, a obra literária parece-nos apenas uma inspiração.

As transformações operadas por Almodóvar, no entanto, revelam, qual a obra de uma aranha tecendo sua teia

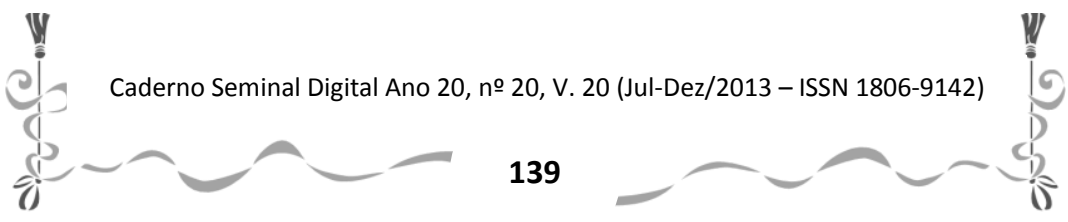


(mygale $=$ tarântula), um delicado diálogo no qual prevalecem, inevitavelmente, as distintas referências do cineasta, que cria, a partir de sua leitura, uma nova obra, sua versão fílmica, com a marca de sua própria identidade artística. Interessa-nos, pois, aqui identificar algumas dessas transformações, que aparentemente "traem" o original de Jonquet, mas que, na verdade, traduzem o ADN de cada artista, mantendo em comum, apenas alguns alelos, que garantem simultaneamente seu parentesco e suas distintas identidades.

Richard Lafargue é um conceituado cirurgião plástico da região parisiense. Quem por ventura observar sua rotina verá que ele mora num refinado subúrbio com uma linda mulher, Ève, e que divide seu dia entre o hospital, em Paris, e sua clínica em outro subúrbio. Por vezes, o casal desloca-se para ir a festas, restaurantes, a uma garçonière no centro de Paris, ou a uma clínica de repouso mais afastada, na região oeste. Estas são as primeiras informações que são fornecidas ao leitor. O que o leitor descobre com o desenrolar da trama é uma terrível história: Ève, na verdade é Vincent. Richard acredita que Vincent violentou sua filha Viviane e é o responsável por sua insanidade. Após um período de cárcere e de tortura psicológica, Richard submete Vincent a uma vaginoplastia, mudando seu sexo. Prisioneira de Richard, Ève mantém um terrível segredo relacionado ao estupro de Viviane, revelado apenas ao final da narrativa. Paralelamente ao cotidiano do pseudo-casal, temos a personagem de Alex

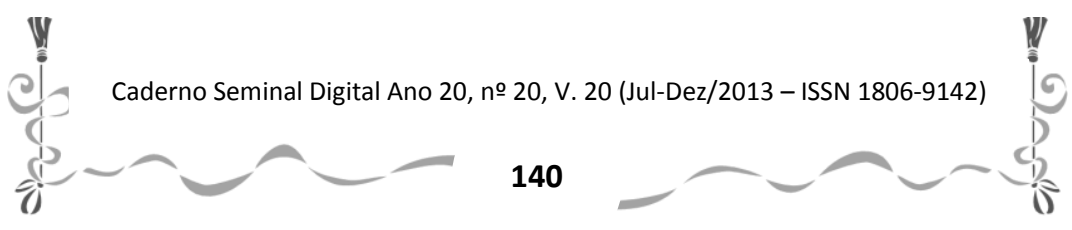


Barny, um marginal em fuga. Alex acaba de roubar um banco e matou um policial. Escondido em uma casa no sul da França, ao ver uma entrevista do Dr. Lafargue na televisão, logo se imagina com um novo rosto, resultado de uma cirurgia plástica. Para tanto, elabora um plano e retorna à região parisiense. Durante dias, Alex observa a rotina do médico. Finalmente, sequestra Ève, pensando que se trata da esposa de Richard e chantageia-o para realizar a operação. Evidentemente, o médico joga o jogo de Alex e, após sedá-lo, interroga-o e descobre onde é o cativeiro de Ève, resgatandoa.

O que não foi ainda revelado a nossos leitores em nossa tentativa em resumirmos Mygale, para passarmos efetivamente a um cotejo com $A$ pele que habito? Durante a fase inicial de cárcere, Vincent começa a desenvolver uma relação de dependência psicológica com seu sequestrador/torturador, esboçando sintomas da conhecida Síndrome de Estocolmo. Após mudar o sexo de Vincent/Ève, Richard obriga-o a prostituir-se, inicialmente nas ruas, depois, na garçonière parisiense, tornando-se voyeur dos encontros de Ève com seus habitués sadomasoquistas. As idas à garçonière e à casa de repouso onde está Viviane acontecem quando Richard tem seus surtos de raiva contra Ève. Esta, além de dedicar-se à pintura, muitas vezes retratando e ridicularizando Richard, para provocá-lo, cantarola ou toca

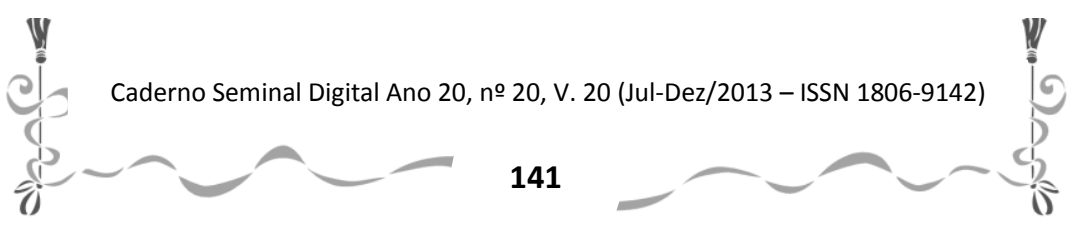


Caderno Seminal Digital

repetidamente ao piano a canção The man I love, dos irmãos Gershwin: fundo musical do estupro de Viviane.

O leitor descobre igualmente que Vincent e Alex eram grandes amigos e que foi efetivamente Alex quem estuprou Viviane, segredo revelado apenas ao final da trama, após a morte de Alex, como um trunfo de Vincent/Ève sobre Richard. Liberada por Richard após a morte de Alex, Ève permanece na mansão, sem imaginar uma perspectiva além de seu cárcere. Assim termina Mygale. Vale apreciarmos en passant, no entanto, alguns recursos narrativos utilizados por Jonquet em seu thriller para manter o suspense, revelando pouco a pouco todo o horror de sua ficção.

A narrativa in media res que nos apresenta um cotidiano burguês beirando o idílico é subitamente entrecortada por uma distinta narrativa em itálico:

... Lembre-se. Era uma noite de verão. Fazia um calor horrível, úmido, um fardo insuportável. Um temporal estava prestes a cair. Você pegou sua moto e fugiu pela noite. $O$ ar noturno, pensava, me fará bem.

Você ia rápido. O vento inflava sua camisa, que estufava e estalava. Insetos esmagavam-se em sua viseira, seu rosto, mas você não sentia mais calor.

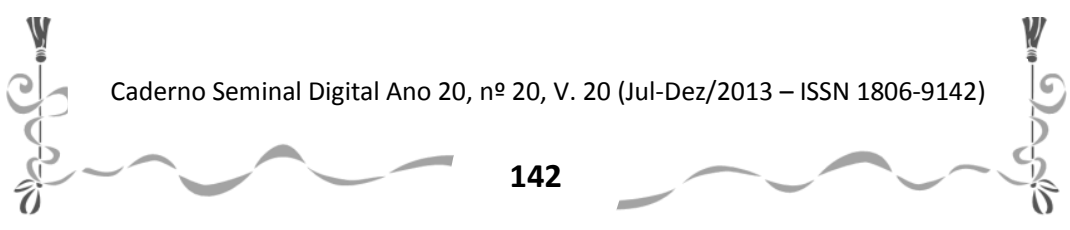




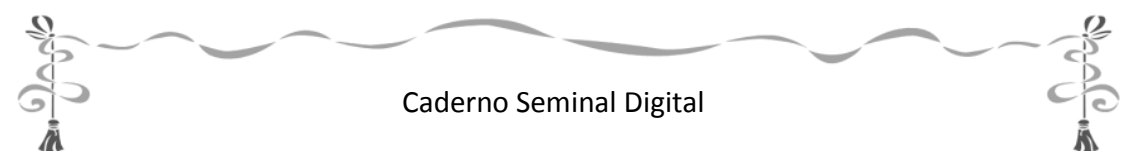

Levou tempo até você começar a se preocupar com a presença daqueles dois faróis brancos, esburacando a escuridão no seu encalço. Dois olhos elétricos, apontados para você, implacáveis. Inquieto, você exigiu tudo do motor da 125, mas o carro que o perseguia era potente, mantendo-se sem dificuldade na sua cola.

Você ziguezagueando na floresta, angustiado no início, depois em pânico diante da insistência daquele olhar que não o largava. Pelo retrovisor, percebeu que o motorista estava sozinho. Não parecia querer aproximar-se. (JONQUET, 2011, p.20-21)

Essas interferências corresponderão aos flashbacks de Almodóvar. Não cabe aqui nos determos nos trechos em itálico, na óbvia importância da utilização da segunda pessoa (masculina e, após a vaginoplastia, feminina) e do discurso indireto livre que reforçam o suspense em Jonquet e que são, a nosso ver, elementos essenciais da metaficção em Mygale. Vale, sim, ressaltarmos que o segmento acima é um dos raros trechos de Jonquet fielmente reproduzidos por Almodóvar em A pele que habito.

O espectador do filme, curioso em tornar-se leitor de Mygale, surpreender-se-á de imediato com as diferenças entre as duas obras: somos transportados da França para

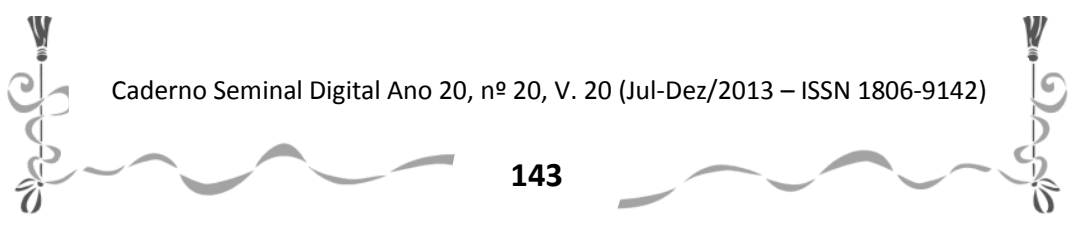


Toledo, na Espanha; Richard Lafargue, na tela, torna-se Robert Ledgard; Ève é Vera; a personagem de Alex Barny não existe no filme tal qual no livro, mas Almodóvar lega-nos o caricato Zeca, irmão brasileiro de Robert, que seduz sua esposa, provocando o acidente que a desfigura; a empregada Line, de Jonquet, não brilha como a governanta Marilia, mãe de Robert e Zeca (aliás, não fica claro se Robert e Marília são igualmente brasileiros, porém, em entrevista, Almodóvar afirma que a menção ao Brasil é efetivamente por nossa tradição em cirurgia plástica),... eis apenas alguns elementos alterados pelo cineasta espanhol.

Inicialmente, parece-nos inevitável que Almodóvar ambiente sua versão do Dr. Frankeinstein em uma cidade tão mí(s)tica como Toledo, hispanizando a ficção francesa. Rapidamente constatamos o jogo que se estabelece na (não) identificação nominal das personagens do texto e da tela. Fica flagrante o processo de desconstrução e reconstrução de Almodóvar, a partir dos nomes das personagens, de suas "identidades".

Se o médico francês batiza Vincent com o nome de Ève/Eva, a mulher original, evocando no leitor referências bíblicas da criação; para Almodóvar, o feminino se traduzirá por Vera, a verdadeira, a lúcida. E se Ève dedica-se à pintura e à música, Vera manterá sua lucidez pela meditação, pela yoga, pela arte em nas esculturas de Vincent/Vera/Louise Bourgeois. Nas paredes de seu cárcere lemos a frase de Ernest

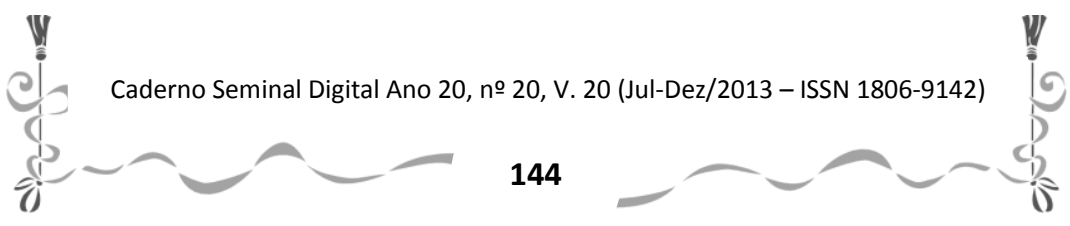


Caderno Seminal Digital

î.

Hemingway escrita por Vincent/Vera: “El arte es garantía de salud", a arte é garantia de sanidade.

Nos créditos do filme, lemos o agradecimento do espanhol à escultora francesa: "Gracias a Louise Bourgeois, cuya obra non solo me ha emocionado, sino que sirve de salvación al personaje de Vera" Pedro Almodóvar. Mas Vera não é apenas Vera, é Vera Cruz, numa nítida sugestão não somente às referências cristãs (paixão, penitência, salvação...) como também brasileiras do cineasta. Essa é, aliás, apenas uma das referências brasileiras do filme. Quando a mulher de Robert ouve sua filha cantando no jardim, levanta-se e dirigese à janela. Em seu percurso, ao som da canção brasileira "Pelo amor de amar" (de autoria de José Toledo e Jean Manzon) surge na parede de seu quarto uma tela de Tarsilla do Amaral, "Paisagem com ponte".

"The man I love" encontra, pois, correspondência em "Pelo amor de amar", canção já utilizada pelo cineasta francês Marcel Camus em "Os bandeirantes" (1960). As canções têm a mesma função, mnemônica: elas estão na origem de tragédias e são retomadas acionando a lembrança das mesmas, provocando sofrimento ou mesmo, outras tragédias.

Em Mygale, o leitor descobrirá, pouco a pouco, que "The man I love" aparece primeiramente no casamento em que Viviane foi estuprada e é retomada por Ève para provocar Richard, despertando nele a lembrança do abuso contra sua filha. Ocorre que a letra da música ironicamente diz que um

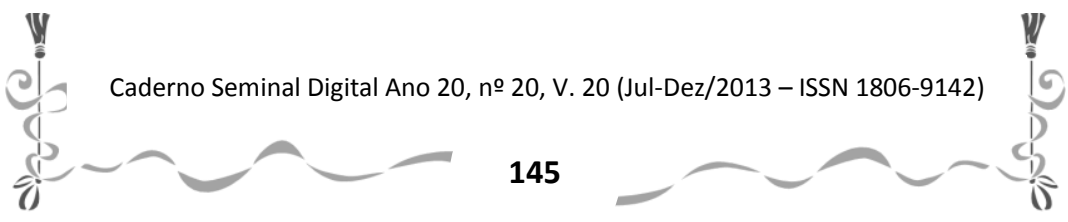


dia um homem virá e que vai construir uma casa da qual a amada nunca sairá! Reflete, assim, a situação ambígua de Vincent/Ève e Richard.

Em A pele que habito, a canção "Pelo amor de amar" é primeiramente cantada pela filha de Robert, Norma, no jardim de sua casa e é justamente o que provoca o suicídio da mãe, Gal, que finalmente se vê desfigurada no vidro da janela ao ir ouvir a filha cantando. Em seguida, Norma, em outro jardim, da casa em que ocorre um casamento, está com Vincent, que acaba de conhecer. Vicente está sobre Norma, prestes a consumar a relação sexual consensual, quando subitamente a cantora começa a entoar "Pelo amor de amar" na casa. Despertada a lembrança da morte da mãe, Norma surta. Vicente tenta trazê-la à razão, esbofeteando-a: ela desmaia e ele parte.

Viviane, cujo nome deveria significar "cheia de vida/vivaz" vegeta em uma casa de repouso após o ocorrido. É necessário esclarecermos igualmente que a insanidade que afasta Norma de tudo o que possamos considerar "normal", até seu suicídio, surge de um grande mal entendido: encontrada desfalecida por seu pai que tenta reanimá-la, ela acredita ter sido abusada pelo próprio pai e não pelo jovem Vicente.

A adoção de outros nomes por Almodóvar produz ecos e reflexos entre o texto literário e o filme, duplicando personagens, personalidades. Tal espelhamento ultrapassa o

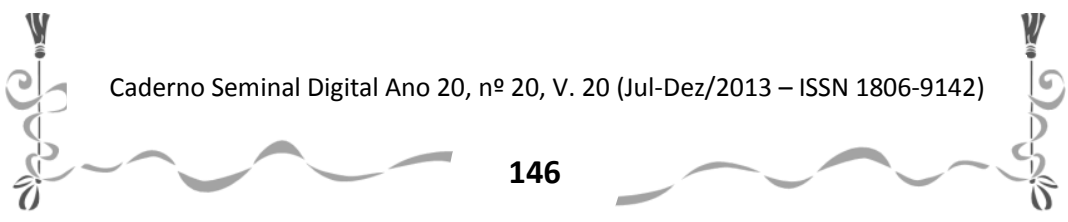


Caderno Seminal Digital

"nomear", identificar. Em Almodóvar, teremos, por exemplo, dois estupros: o suposto abuso de Vicente que, ele próprio é desdobrado no mal entendido entre Norma e seu pai, e a defloração de Vera por Zeca. O que parece ser e o que realmente é, o bem e o mal que nos habitam; a sanidade e a loucura, o feminino e o masculino; Vicente, o jovem tosco e Vera, a mulher refinada.

Tanto Mygale quanto A pele que habito tratam da questão da identidade a partir do gênero. $O$ legado do relato de violência e terror da ficção de Jonquet ao leitor é pleno de angústia e desesperança. Almodóvar extrai dessa história de horror a possibilidade de futuro, a partir do feminino, na personagem de Cristina, em seu olhar de desejo e no reconhecimento de Vicente, fato que não surpreenderá os cinéfilos minimamente conhecedores do conjunto da obra de Almodóvar e do tratamento dado às figuras femininas pelo cineasta. Resta que, o único nome que foi efetivamente mantido pelo cineasta é Vincent/Vicente, reafirmado na derradeira réplica "Soy Vicente", pois modificou-se a forma, mas não o fundo. Transformou-se a aparência, mas não a essência e o que foi e permanece é Vicente, no texto e na tela, no passado e no presente.

Finalmente, além da narrativa em si, as referências visuais, sobretudo picturais e mitológicas, exploradas por Almodóvar em A pele que habito suscitam, esteticamente, de

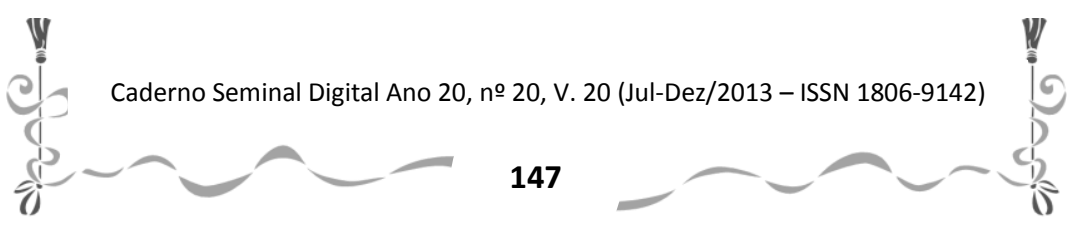


Caderno Seminal Digital

î.

forma especular, o grotesco e o sublime, cotejando-os e contrapondo-os inúmeras vezes, como veremos a seguir.

\section{PIGMALIÃO \& GALATÉIA E BACO \& ARIADNE: MITOS DE AMOR CHAMADOS PARA O DIÁLOGO INTERTEXTUAL}

$\mathrm{Na}$ versão cinematográfica, cujo roteiro foi assinado pelos irmãos Pedro e Agustín Almodóvar, à medida que os fatos da narrativa iniciada in medias res vão sendo apresentados aos espectadores, não há como os mais atentos não distinguirem a relação homológica que começa a se descortinar entre os elementos constitutivos da narrativa cinematográfica e aqueles da narrativa mitológica de Pigmalião e Galatéia. Robert Ledgard, o cirurgião plástico do filme, faz às vezes de deus pagão e determina uma metamorfose em Vicente, como vingança por acreditar que o rapaz era o responsável pelo suicídio de sua filha Norma (Viviane no texto literário fonte), também é o escultor da mulher ideal - Vicente/Vera, e metamorfoseia sua pele antes frágil para uma pele à prova de fogo e picadas de insetos, ele a esculpe, nos mínimos detalhes, até ficar idêntica à sua esposa, que fora vítima de um incêndio, tempos antes. Para que essa sutileza da homologia com o mito não passe despercebida aos olhos do espectador atento, uma evidência é lançada: o nome da pele criada em laboratório pelo $\mathrm{Dr}$. Ledgard é $\mathrm{GAL}$, ele criou sua Galatéia, e com ela moldou sua mulher perfeita.

O Pigmalião clássico foi um exímio escultor da ilha de Chipre (terra da deusa Afrodite), que, indignado com a

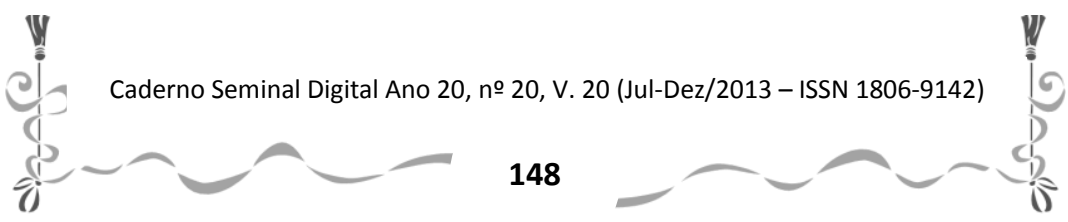


prostituição a que se entregavam as mulheres da cidade, optou por viver isolado e se entregar à sua arte, como o fez o cirurgião plástico Robert Ledgar, no filme, que se isolou em sua clínica-mansão, o El Cigaral. Vale relembrar que no texto de Jonquet, Richard obriga sua "criação" a se prostituir, reforçando a relação especular da teia narrativa Jonquet/Almodóvar/referências.

O Pigmalião grego desprezava o casamento, pois afirmava que nenhuma mulher viva poderia ser tão bela como aquelas que ele criava com as suas próprias mãos. Foi então que começou a trabalhar arduamente e, gradualmente, a depositar seu amor numa escultura de marfim, que esculpiu à imagem de uma mulher. No filme, Ledgard trabalhou arduamente no novo corpo de Vicente/Vera, e deu a ele as feições e as formas de sua esposa Gal (a quem havia homenageado ao atribuir seu nome à pele que criou, conforme mencionado anteriormente).

A figura esculpida pelo artista do mito clássico foi de tão grande beleza, nela ele trabalhou com tanta arte e técnica a ponto de fazê-la parecer com uma humana, e ter ares de figura viva. Segundo Grimal (2005, p.373), o escultor apaixonou-se por sua obra, e a aperfeiçoou mais e mais, ansiando por poder transformar o marfim em carne e osso. Deu-lhe o nome de Galatéia, que em grego significa "branca como o leite", ornamentou-a com joias e tecidos, coroou sua cabeça com flores, mas tudo se revelou em vão, pois ela

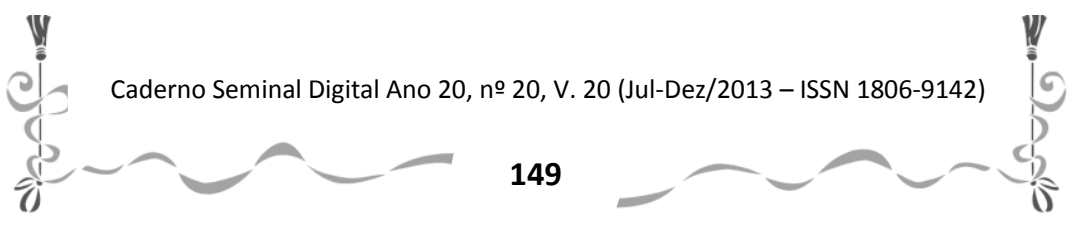


continuava fria, feita de matéria inerte. Na trama do filme o escultor Robert também se apaixonou por sua obra, quando finalizada, perfeita, admirava-a pelas imagens das câmeras que a mostravam fazendo alongamentos, posições de yoga ou escritos e imagens nas paredes de sua câmara/prisão. Para ela, Robert levava ópio, convidava-a a o dividir com ele, para deleitarem-se juntos com o alucinógeno.

$\mathrm{Na}$ antiguidade clássica pagã, em Chipre, quando chegaram as festas da deusa da ilha Afrodite, Pigmalião levouIhe ricas oferendas, suplicou-lhe encontrar uma mulher igual à que ele esculpira. Comovida, a deusa do amor ouviu seu pedido e deu vida à escultura. Ao chegar a casa, o escultor percebeu que Galatéia já não tinha um olhar fixo nem vazio e em suas veias corria sangue. No encontro das mãos de ambos, ele comprovou que a mulher de seus sonhos estava ali para amá-lo. Casaram-se e tiveram filhos, Pafo e Metarme.

Já no texto cinematográfico contemporâneo, o desfecho não é tão feliz assim. Robert entusiasma-se com sua Galatéia. Depois do estupro bizarro cometido pelo meio-irmão fantasiado de tigre, e sua morte, pelas mãos de Robert, que defende Vicente/Vera das garras do pseudo-felino, uma transformação ocorre, o cirurgião-escultor vê transformada em viva sua obra escultórica e a quer para si. Acredita nela e em seu amor, crê que poderão viver juntos, dividir o mesmo espaço, conviver em equilíbrio. Mas ela não se mostra fiel e submissa como a Galatéia do mito, e o espectador que já viu o

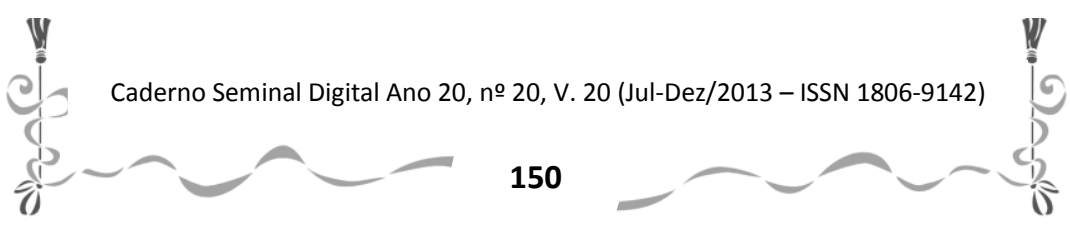


Caderno Seminal Digital

filme sabe como será o desfecho dessa narrativa de amor, ódio e metamorfose.

Afrodite (para os gregos, ou Vênus para os romanos) também é invocada no texto cinematográfico dirigido por Pedro Almodóvar, pois está presente no cenário, em duas reproduções de grande dimensão pelas quais o médico passa no corredor dos quartos, após subir a escadaria da sala. É em frente a elas que Zeca, em pele de tigre, domina e imobiliza sua presa (Vicente/Vera). São duas reproduções de pinturas famosas do pintor italiano Tiziano Vecellio: "Vênus de Urbino", de 1538, e "Vênus com Organista e Cupido", de 1548. Yago Garcia afirma que Almodóvar declarou que as inseriu em sua obra para mostrar que "antes, en esa casa [El Cigarral] se cultivaba la belleza" (GARCIA, s/p).

Outra pintura no cenário do filme que também evoca mitos é "Dioniso encontra Ariadne em Naxos", do artista espanhol Guillermo Pérez Villalta, pintada em 1985 e que faz parte da coleção particular de Pedro Almodóvar.

Caderno Seminal Digital Ano 20, no 20, V. 20 (Jul-Dez/2013 - ISSN 1806-9142)

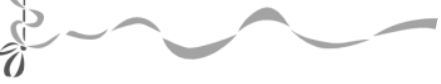

151

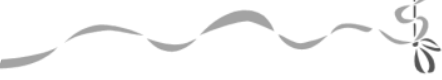



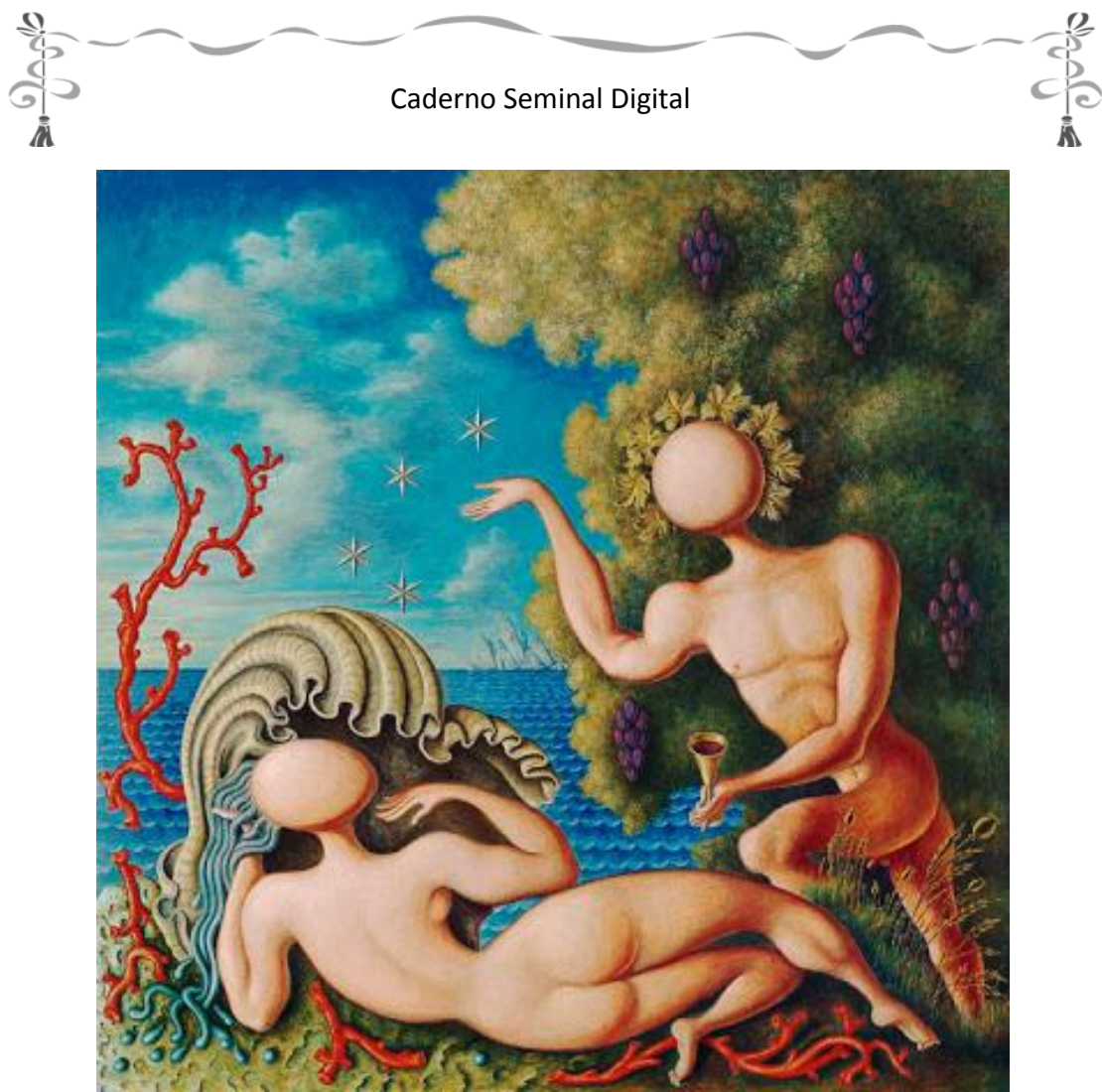

Figura 1: "Dioniso encontra Ariadne em Naxos"

Grimal (2005, p.45-6) conta que, ao fugir da ilha de Creta, na qual reinava Minos, após vencer o Minotauro, ao qual eram oferecidos jovens em sacrifício, Teseu levou consigo a princesa Ariadne. Ela havia auxiliado na empreitada, dandoIhe o novelo de fio que o conduziu de volta à entrada/saída do Labirinto, visto que Ariadne havia amarrado a ponta do fio na

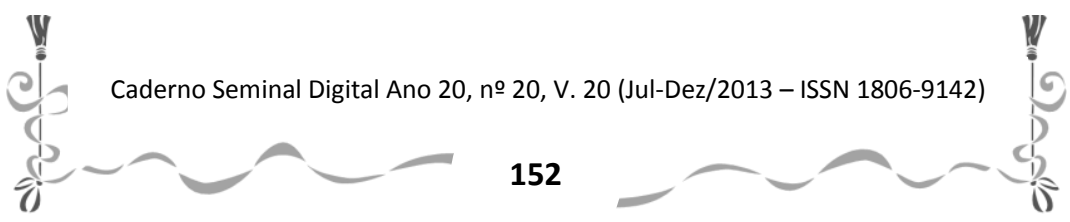


Caderno Seminal Digital

î.

porta, e Teseu desenrolado o novelo até encontrar o monstro de cabeça de touro, e, depois de vencê-lo em luta, enrolara novamente o novelo, até sair do labirinto construído por Dédalo.

Ariadne, "fugiu com Teseu para escapar à cólera de Minos. Contudo, não chegou a Atenas. Tendo feito escala na ilha de Naxos, Teseu abandonou-a, adormecida, junto ao mar" (GRIMAL, 2005, p.46). Uma das explicações do motivo de tal abandono é a de que, foi avisado pelo deus Dioniso que Ariadne não estava destinada a ele, mas sim ao deus do vinho. Teseu deixou-a, então, dormindo na ilha, e seguiu viagem com seu barco e sua tripulação. Ao acordar, Ariadne viu-se abandonada, mas em poucos minutos, recebeu a visita do deus pagão, que, seguido de seu cortejo, trouxe-lhe novamente a alegria.

Dioniso é conhecido como o deus pagão que ensinou à humanidade o cultivo da uva e a fabricação do vinho a partir dela. Essa bebida regava suas festas, e levava aqueles que a ingeriam em grande quantidade ao êxtase, por esse motivo ficou conhecido como "deus da vinha, do vinho e do delírio místico" (GRIMAL, 2005, p.121).

$\mathrm{Na}$ pintura de Villalta, a bebida ligada a Dioniso aparece na taça que a figura masculina (o deus pagão em pessoa) segura com a mão esquerda, e sua fabricação é invocada pela inserção de cachos de uva na árvore representada no segundo plano, logo atrás de Dioniso que

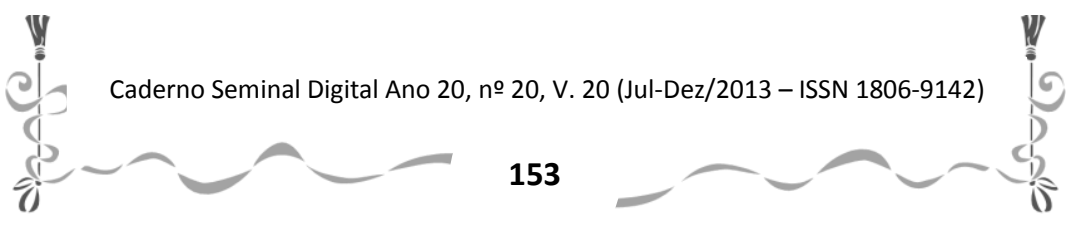


leva aquele conteúdo responsável pela condução ao delírio místico, ao êxtase, à princesa Ariadne, de costas para o leitor da tela, estendida na horizontal, saindo de uma concha (objeto que remete ao nascimento da deusa feminina do amor e da beleza Afrodite e ao símbolo do útero materno), representando o momento em que, após acordar, se vê abandonada pelo amado Teseu, mas já encontra aquele que a elevará a deusa. Ele lhe oferece a oportunidade do êxtase no amor, representado pela taça de vinho.

Na tela, ao fundo estão o mar, no qual já desapareceu o barco do herói Teseu, e o céu, no qual já figura a coroa de estrelas do diadema de ouro com o qual Dioniso presenteará a amada durante as núpcias. Grimal (2005, p.46) afirma que "Este diadema tornou-se depois uma constelação".

Dois aspectos interessantes podem ligar à inserção desse item pictórico ao cenário do texto fílmico de Almodóvar: 1) na cena, ele está no quarto do médico, que chega, retira o paletó e pega uma caixa com ópio, para levá-lo à mulher que ele vê, por meio das câmeras, em uma tela colocada em seu quarto, como Dioniso levou o vinho que conduziria Ariadne ao êxtase;

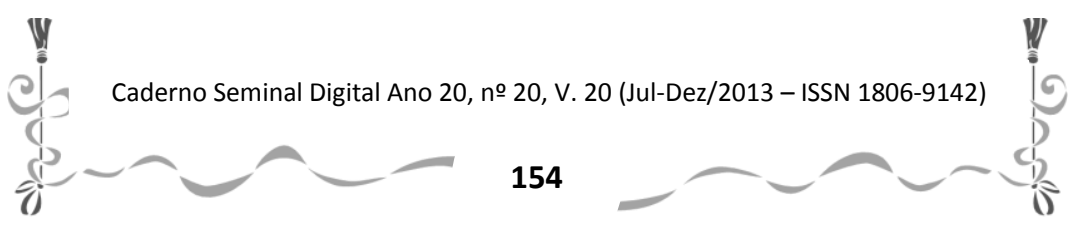



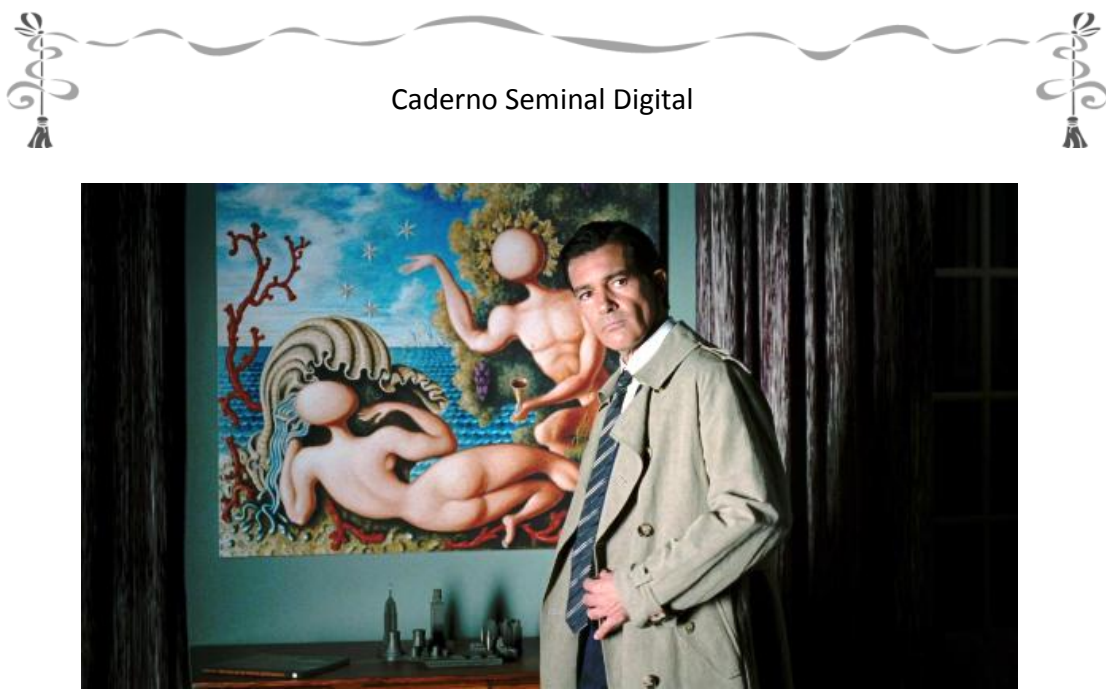

Figura 2: Robert Ledgard (Banderas) em frente à pintura "Dioniso encontra Ariadne em Naxos" Cena do filme A pele que habito

e 2) a pintura de Villalta faz referência a uma outra pintura fonte, datada do Renascimento Italiano, também de Tiziano Vecellio, como as Vênus (nome romano de Afrodite) que citamos anteriormente, e cujas cópias se encontram em outra cena já comentada, trata-se do "Baco e Ariadne" (Baco é o nome romano de Dioniso)

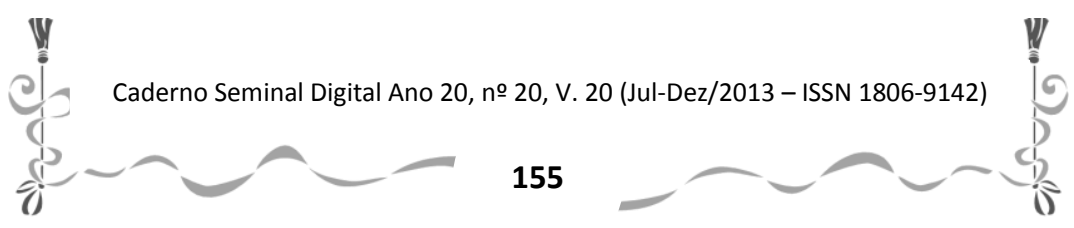



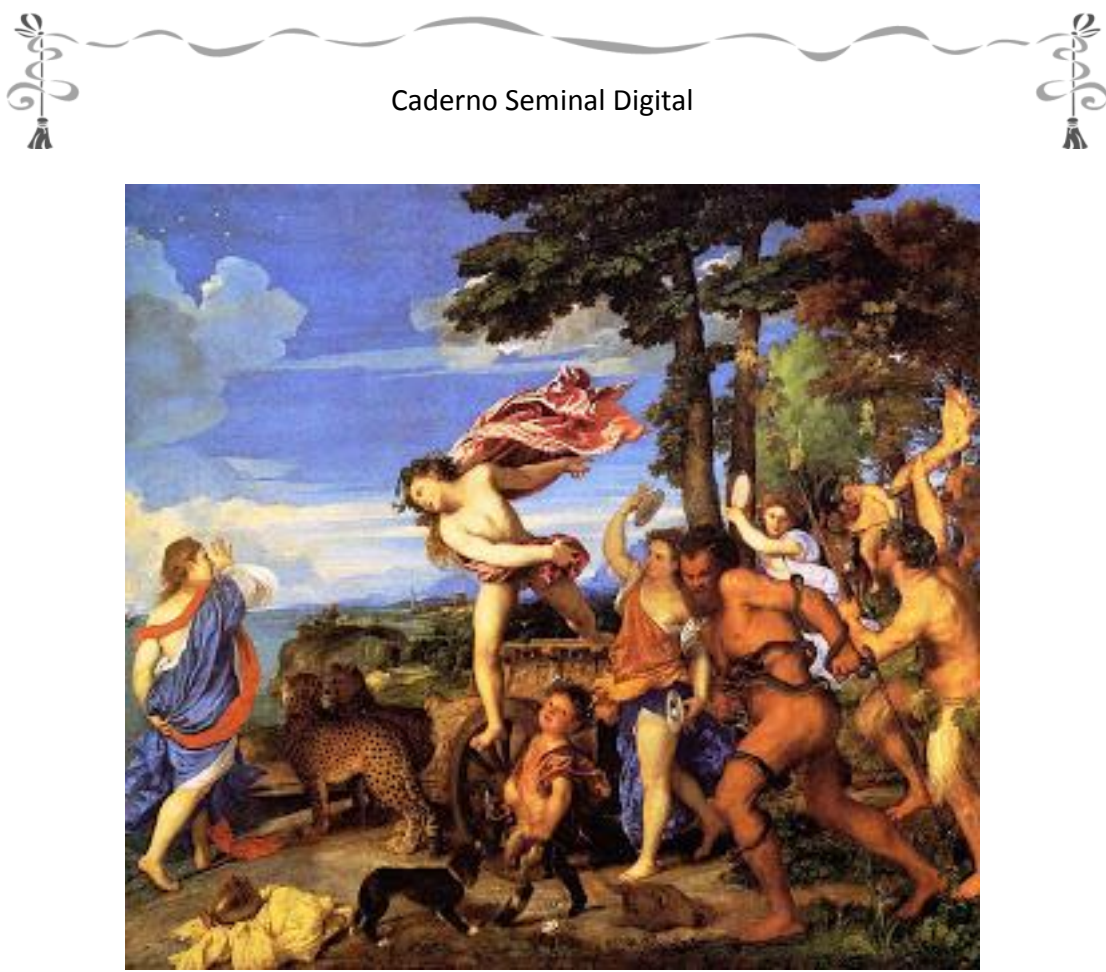

Figura 3: "Baco e Ariadne", Tiziano Vecellio, 1520-1523

Na pintura de Villalta, os elementos constitutivos da representação são reduzidos ao essencial, pois somente os actantes Dioniso (Baco) e Ariadne são representados com os corpos inteiramente nus. A representação do nu para simbolizar a beleza e o vigor físico que espelha a beleza e 0 vigor intelectual dos personagens representados foi um dos elementos da estética clássica. O pintor contemporâneo espanhol retoma de maneira inusitada tal elemento ao não atribuir feições aos rostos. Porém, dá-lhes forma oval, o que, a

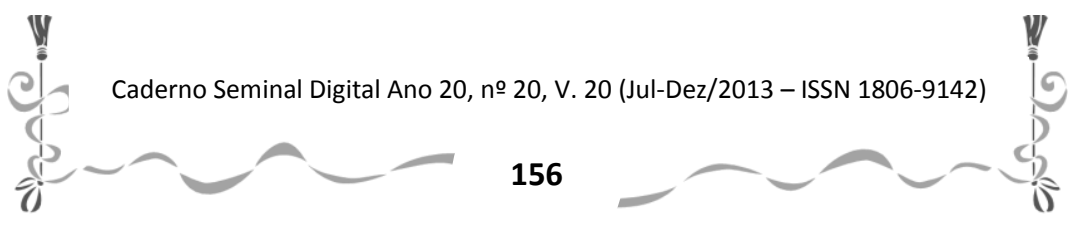


Caderno Seminal Digital

Â

nosso ver, simboliza a possibilidade de nascimento, de criação ou de recriação que cada intelecto humano (residente na cabeça dos indivíduos) pode trazer em si. O vinho e a taça resumem todo o cortejo de Baco representado no texto pictórico de Tiziano.

A disposição diagonal das duas figuras, no entanto, é conservada intacta: o deus do vinho olha a amada de cima (do quarto superior direito, se dividirmos a tela em quatro partes iguais, criadas pelo entrecruzar-se de uma linha horizontal e uma vertical que dividem em duas metades cada uma das direções, resultando delas dois quartos acima e dois abaixo). Enquanto isso, Ariadne, mesmo que não esteja em pé, como na pintura de Tiziano, olha Dioniso de baixo, do quarto inferior esquerdo da representação pictórica. O mar, o céu e a coroa de estrelas são mantidos na representação de Villalta, ambos no terceiro plano da representação, tomando todo o quarto superior esquerdo da pintura. É evidente que Villalta dialogou com Tiziano, e que Almodóvar dialogou com Thierry Jonquet, Tiziano e Villalta.

\section{A INVOCAÇÃO DE LOUISE BOURGEOIS}

E uma última referência à arte que merece ser retomada em nosso estudo: é aquela feita à artista plástica Louise Bourgeois (Paris, 1911 e New York, 2010), francesa radicada nos Estados Unidos, país no qual viveu o final de sua vida. Numa cena, ainda no início do filme, a paciente/prisioneira Vicente/Vera recebe livros para ler em

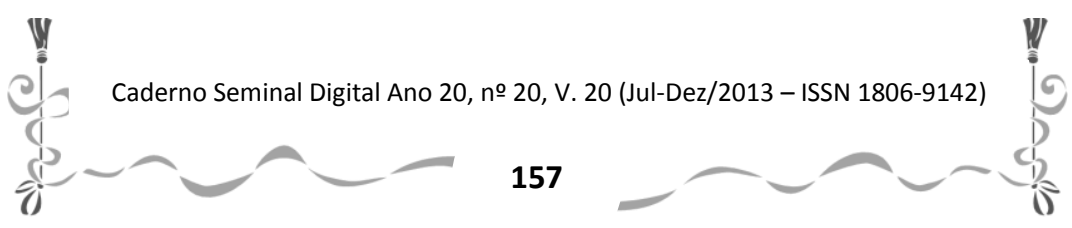


Caderno Seminal Digital

î.

sua câmera/prisão e entre eles está um que contém a obra da artista francesa. O título, estampado em grandes letras na capa, traz o nome de Louise. Existem cópias de desenho e de escultura em mármore da artista plástica (que representam o corpo nu de mulher tendo sua cabeça, seus ombros, braços e parte dos seios encerrados dentro de uma casa) são copiados à mão pela personagem cativa do Dr. Ledgard, na parede que transforma em mural ao fazer nela várias inscrições e desenhos.

O primeiro desenho inspirado na obra de Louise está no quarto superior esquerdo da imagem a seguir, antes da personagem Vicente/Vera, na linha de sua cabeça; o segundo desenho está no quarto inferior direito, logo após a coluna, e representa um corpo nu deitado:

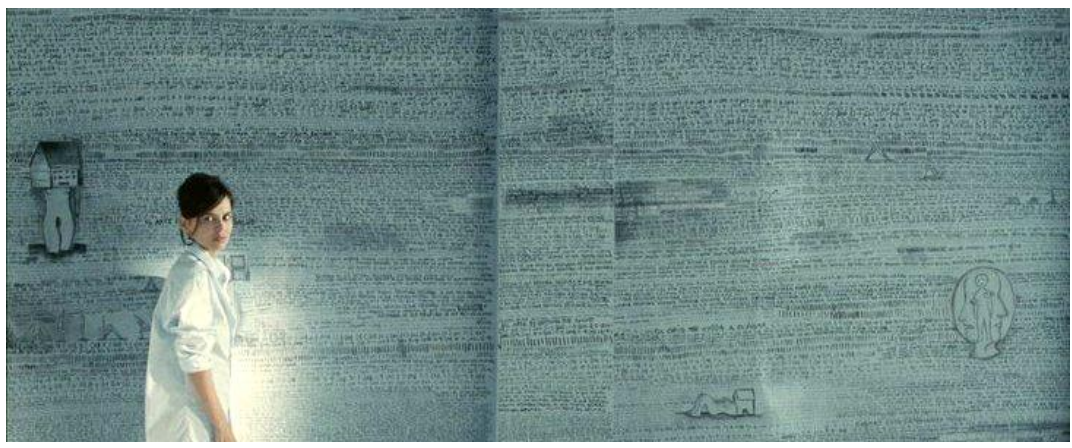

Figura 4: Vicente/Vera e a parede mural

Cena do filme $A$ pele que habito

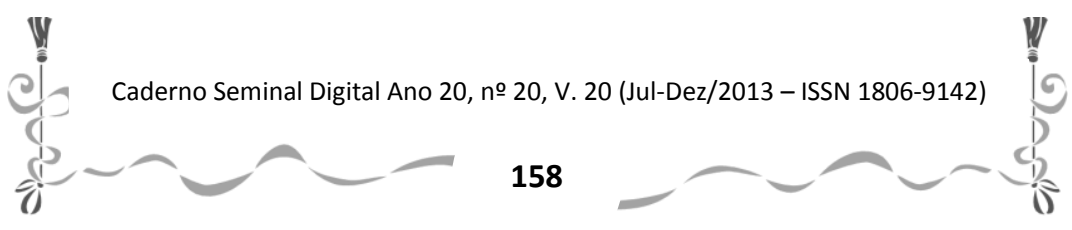


Toda a obra de Louise Bourgeois explora os temas ligados à mulher, e um deles é sua prisão no lar, sua prisão no papel que foi atribuído a ela, muitas vezes não desejado, mas vivido como uma imposição. Nas duas obras tomadas em diálogo intertextual no filme, esse tema é invocado ao ser inserido na manifestação na parede feita pelo/a prisioneiro/a que usa como material de expressão o lápis de maquiagem que se nega a usar em seu rosto, mas que utiliza para cobrir com desenhos e frases que manterão sua integridade interior durante o período da prisão.

Almodóvar, Jonquet e Bourgeois trabalham com a questão do gênero e do desejo e aparecem reunidos pelo primeiro de forma notável.

Enfim, por meio da inserção de elementos às vezes imperceptíveis para espectadores não tão atentos, como as ilustrações, reproduções e pinturas nas paredes, Almodóvar constrói novas relações interpretativas a partir de diálogos intertextuais com obras artísticas de Tiziano Vecellio, Guillermo Pérez Villalta e Louise Bourgeois. Ele amplia o universo dos significados que vão além daqueles do textofonte literário de Thierry Jonquet, com o qual não cessa de dialogar, fiel à herança genética original.

O cineasta ainda fornece, a nós, espectadores, geralmente surpresos e chocados ao final da primeira vez que vemos o filme, não somente sua "replicação", releitura e recriação de Mygale, mas, veiculadas por suas referências e

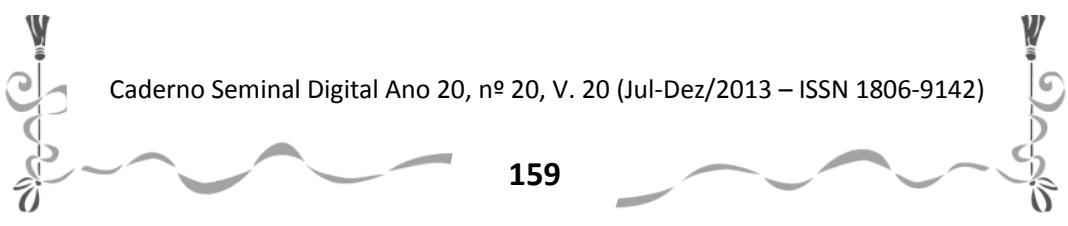


Caderno Seminal Digital

stética única, possibilidades infindáveis de reflexão compreensão dos temas do gênero, do amor, do ódio e do desejo, tão magistralmente trabalhados no singular $A$ pele que habito.

\section{REFERÊNCIAS BIBLIOGRÁFICAS:}

GARCÍA, Yago. Los "easter eggs" culturales de "La piel que habito". Disponível em http://cinemania.es/actualidad/noticias/9483/, acessado em 02/06/2013.

GRIMAL, Pierre. Dicionário de mitologia grega e romana. 5ed. Trad. de Victor Jabouille. Rio de Janeiro: Bertrand Brasil, 2005.

JONQUET, Thierry. Mygale. Paris: Éditions Gallimard, 1989.

. Tarântula. Trad. de André Telles. Rio de Janeiro: Record, 2011.

PELE que habito, A. Direção: Pedro Almodóvar. Produção: Buena Vista International / Canal + España / El Deseo S.A. / FilmNation Entertainment / Televisión Española (TVE) / World Cinema Fund. Espanha, 2011. DVD (133 min), color. Título original: La piel que habito.

Figura 1 "Dioniso encontra Ariadne em Naxos". http://olgatotumrevolutum.blogspot.com.br/2013/04/la-esculturacicladica.html. Acesso em 11/06/2013.

Figura 2: Robert Ledgard (Banderas) em frente a pintura "Dioniso encontra Ariadne em Naxos" e Figura 4: Vicente/Vera e a parede mural. http://dazzloviews.blogspot.com.br/2012/11/dazzloviewingpele-que-habito-la-piel.html. Acesso em 11/06/2013.

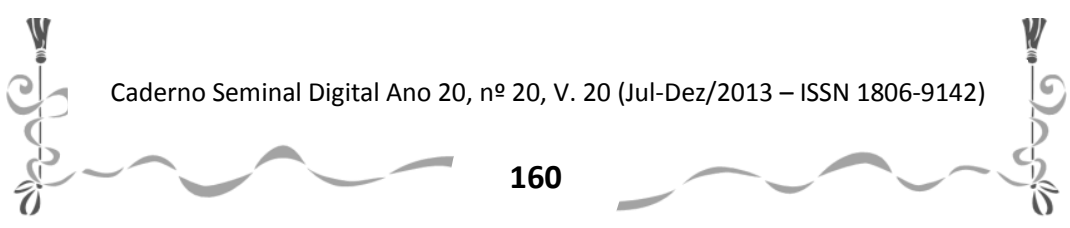




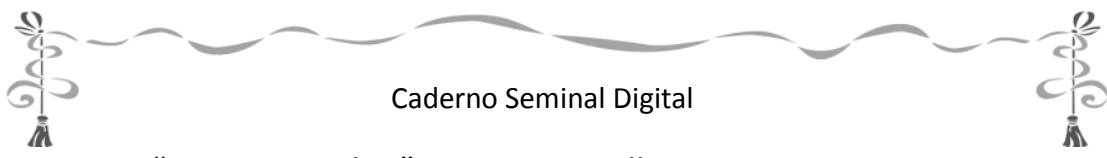

Figura 3: "Baco e Ariadne", Tiziano Vecellio, 1520-1523. http://cirrusminor-cirrus.blogspot.com.br/2011/05/filosofia-daarte.html. Acesso em 11/06/2013.

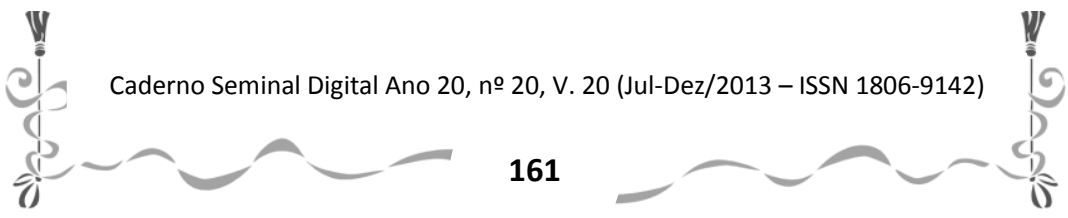

